\title{
The nitrogen-to-protein conversion factor of two cricket species - Acheta domesticus and Gryllus bimaculatus
}

\author{
Tiina Ritvanen, Helena Pastell, Annikki Welling and Marja Raatikainen \\ Finnish Food Authority, Chemistry Unit, P.O. Box 200, 00027 RUOKAVIRASTO, Finland \\ e-mail: tiina.ritvanen@ruokavirasto.fi
}

\begin{abstract}
The Kjeldahl method is the most utilized method for total protein content analysis in food. Using the universal nitrogen-to-protein conversion factor of 6.25 , the protein content of insects is likely to be overestimated due to their chitin content. We have calculated nitrogen-to-protein conversion factors for two crickets, house cricket (Acheta domesticus) and field cricket (Gryllus bimaculatus), which are used for food and feed in Europe. By analyzing their nitrogen and amino acid content we were able to show that a conversion factor of 5.09 could be used for house cricket and 5.00 for field cricket in protein content calculation. Based on these results with a reservation about slight variation in farming conditions, we suggest a nitrogen conversion factor of 5.0 for both crickets.
\end{abstract}

Key words: amino acids, insects, novel foods, protein analysis

\section{Introduction}

One of the emerging trends in European food is entomophagy, i.e., the eating of insects (Santeramo et al. 2018, Patel et al. 2019). Insects are considered to be nutrient-rich and sustainable food. Insect-based food in Europe is not traditional, and many acts are needed to grow their utilization in the food industry, via legislation and consumer insights. In fact, a lot of research is on-going, and studies have shown that food technology can be used to develop the acceptability of insects as a food ingredient (Mancini et al. 2019, Mishyna et al. 2020).

At the moment, the use of house crickets (Acheta domesticus) is permitted in the EU (EC 2019), and an application for the novel food status has been submitted. The field cricket (Gryllus bimaculatus) is primarily used in Europe as feed for insectivorous animals (https://ec.europa.eu/food/safety/novel_food/authorisations/summary-applications-and-notifications_en, 5.4.2019). However, these crickets have traditionally been common edible insects, e.g., in Thailand, in Korea and in Mexico (Jongema 2017).

The nutritional aspects of insects have been widely discussed (Rumbold and Schlüter 2013, Kouřimská and Adámková 2016, Nowak et al. 2016, Patel et al. 2019). As insects are a vast category comprising more than a million known species, there is naturally a large variation in their composition. Moreover, a lot of parameters are known to affect the composition within a certain species: a developmental stage, location, season, feed and gut content (e.g. Kouřimská and Adámková 2016, Nowak et al. 2016). One of the special features in insects is high chitin content in their exoskeletons. Like other non-protein nitrogen (NPN), nitrogen in chitin influences protein analyses, for instance, the Kjeldahl method. If certain food contains more NPN than food in general, the universal nitrogen-to-protein conversion factor of 6.25 used in the Kjeldahl method can lead to overestimation of the calculated protein content. Therefore, some researchers (e.g. Janssen et al. 2017, Jonas-Levi and Martinez 2017) have suggested methods to evaluate more correct nitrogen conversion factors for different insects. Janssen et al. (2017) determined a nitrogen conversion factor of 4.76 in three insect larvae species. It is not known how widely this conversion factor is applicable to other insects.

The Kjeldahl method is widely known and the most utilized method for total protein analysis in food (e.g. Moore et al. 2010, Mæhre et al. 2018). There are numerous method standards for it and food and feed legislation often demands its use. The method has well-known disadvantages in selectivity, reagent consumption and speed, but the shift to other methods is slow, not least because of the economic effect of the protein content. Therefore, it is still important to develop the Kjeldahl method and re-evaluate the nitrogen conversion factors.

In this study, we have calculated nitrogen conversion factors for two crickets, Acheta domesticus and Gryllus bimaculatus, by analyzing their nitrogen and amino acid content. 


\section{Material and methods}

\section{Samples}

The samples were house crickets and field crickets as described in Table 1. Crickets were received from the companies frozen. Crickets are normally sold to consumers dried but this study was done on fresh weight.

Table 1. Background information of the crickets.

\begin{tabular}{lll}
\hline & House cricket & Field cricket \\
\hline Scientific name & Acheta domesticus & Gryllus bimaculatus \\
Life cycle (days) & 32 & 30 \\
Growth temperature $\left({ }^{\circ} \mathrm{C}\right)$ & 30 & 30 \\
Samples from & Entocube Ltd. (Helsinki) & Cricket farm (Loviisa), Nordic Insect Economy \\
Moisture $\left(\mathrm{g} 100 \mathrm{~g}^{-1}\right.$, mean $\left.\pm \mathrm{sd}\right)$ & $69.1 \pm 4.5(\mathrm{n}=5)$ & $69.1 \pm 4.0(\mathrm{n}=5)$ \\
Size $(\mathrm{g}$, mean $\pm \mathrm{sd})$ & $0.25 \pm 0.04(\mathrm{n}=20)$ & $0.76 \pm 0.21(\mathrm{n}=20)$ \\
\hline
\end{tabular}

\section{Nitrogen analysis}

Nitrogen was analyzed by the Kjeldahl principle according to Commission regulation (EC 2009). The sample was digested by strong sulphuric acid (95-97\%) in the presence of $\mathrm{Cu}$ as a catalyst (Kjeltabs, Foss). The acid solution was turned into alkaline with $30 \%$ sodium hydroxide solution. The liberated ammonia was distilled into an excess of $2 \%$ boric acid solution, followed by titration with $0.2 \mathrm{~N}$ sulphuric acid solution. Digestion was carried out with Gerhardt Digestion Unit and distillation with Gerhardt Vapodest. The nitrogen content of eight individual crickets of both species was analyzed.

\section{Amino acid analysis}

Amino acid content of crickets was analyzed according to Commission Regulation (EC 2009). Cysteine and methionine were oxidized to become cysteic acid and methionine sulfone. The sample was oxidized with performic acid at $0{ }^{\circ} \mathrm{C}$ for 16 hours. After oxidation, the sample was hydrolyzed with hydrochloric acid $(\mathrm{HCl}, 6 \mathrm{M})$ at $110{ }^{\circ} \mathrm{C}$ for 24 hours. Tyrosine was analyzed from the unoxidized sample. The hydrolyzed sample was adjusted to $\mathrm{pH} 7$ and derivatized according to the Waters AqqcTag (Milford, Massachusetts, USA) derivatization kit. Amino acids were analyzed with Waters Aqcuity UHPLC (Milford, Massachusetts, USA) with a photodiode array detector using Waters AqqcTag Ultra C18 column $(1.7 \mu \mathrm{m}, 2.1 \times 100 \mathrm{~mm})$ and detected at $260 \mathrm{~nm}$.

The tryptophan content of crickets was analyzed according to Commission Regulation (EC 2009) with some modifications. The sample was hydrolyzed with sodium hydroxide $(\mathrm{NaOH}, 5 \mathrm{M})$ at $110^{\circ} \mathrm{C}$ for 16 hours. After hydrolysis, tryptophan was analyzed with Waters Aqcuity UHPLC with a fluorescence detector using a Waters AqqcTag Ultra C18 column $(1.7 \mu \mathrm{m}, 2.1 \times 100 \mathrm{~mm})$ and detected with fluorescence (ex $285 \mathrm{~nm}$, em $340 \mathrm{~nm}$ ).

\section{Nitrogen conversion factor}

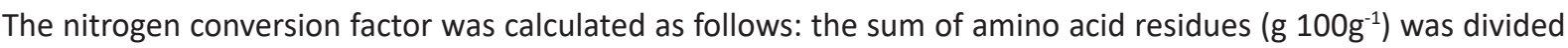

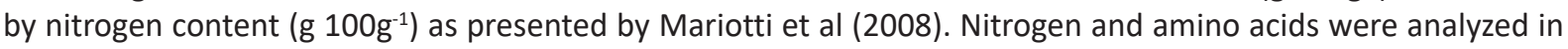
individual crickets. Mean values were used to calculate the nitrogen conversion factor.

\section{Results and discussion}

The results of the amino acid analysis are shown in Table 2 and the results of the nitrogen analysis are shown in Table 3.

The amount of amino acids ( $\mathrm{g} 100 \mathrm{~g}^{-1}$ fresh weight) was higher in the field cricket than in the house cricket, but differences in amino acid profiles ( $\mathrm{mg} \mathrm{g}^{-1}$ protein) were minor (Table 2). The amounts of individual amino acids were not dependent on the size of the cricket (data not shown). 
The current study measured the amounts of amino acids on a fresh weight basis. However, with the use of dry weight reported in Table 1, results can be converted to a dry weight basis (if needed for reference). The amount was lower than the value in the study by Köhler et al. (2019), who analyzed an edible portion of insects. The processing of insects changes the composition, especially the amount of water may decrease considerably. The measured amino acid profile ( $\mathrm{mg} \mathrm{g}^{-1}$ protein) was comparable to previously published amino acid compositions of house crickets (Rumbold and Schlüter 2013, Köhler et al. 2019). The protein conversion factor of 6.25 was used to make comparison possible.

Table 2. Amino acid concentrations (mean $\pm \mathrm{sd}$ ) of the crickets as $\mathrm{g} 100 \mathrm{~g}^{-1}$ fresh weight as well as proportions of individual amino acids as $\mathrm{mg} \mathrm{g}^{-1}$ protein. $\mathrm{n}=18$, except $\mathrm{n}=9$ for cysteine, methionine, tyrosine and tryptophan

\begin{tabular}{|c|c|c|c|c|}
\hline & \multicolumn{2}{|c|}{ House cricket } & \multicolumn{2}{|c|}{ Field cricket } \\
\hline & g $100 g^{-1}$ & $\mathrm{mg} \mathrm{g}^{-1}$ protein & g $100 g^{-1}$ & $\mathrm{mg} \mathrm{g}^{-1}$ protein \\
\hline Alanine & $1.35 \pm 0.17$ & 83 & $1.93 \pm 0.31$ & 90 \\
\hline Arginine & $0.89 \pm 0.10$ & 54 & $1.14 \pm 0.10$ & 53 \\
\hline Asparagine + Aspartic acid & $1.37 \pm 0.17$ & 84 & $1.97 \pm 0.32$ & 92 \\
\hline Cysteine & $0.15 \pm 0.02$ & 8.9 & $0.16 \pm 0.03$ & 7.4 \\
\hline Glutamine + Glutamic acid & $1.98 \pm 0.20$ & 120 & $2.44 \pm 0.29$ & 114 \\
\hline Glycine & $0.93 \pm 0.10$ & 57 & $1.24 \pm 0.18$ & 58 \\
\hline Histidine & $0.38 \pm 0.04$ & 23 & $0.52 \pm 0.05$ & 24 \\
\hline Isoleucine & $0.69 \pm 0.07$ & 42 & $0.92 \pm 0.08$ & 43 \\
\hline Leucine & $1.22 \pm 0.13$ & 75 & $1.65 \pm 0.14$ & 77 \\
\hline Lysine & $0.97 \pm 0.13$ & 59 & $1.14 \pm 0.15$ & 53 \\
\hline Methionine & $0.30 \pm 0.03$ & 18 & $0.35 \pm 0.03$ & 16 \\
\hline Phenylalanine & $0.63 \pm 0.06$ & 39 & $0.74 \pm 0.10$ & 34 \\
\hline Proline & $1.00 \pm 0.09$ & 61 & $1.25 \pm 0.09$ & 58 \\
\hline Serine & $0.68 \pm 0.06$ & 42 & $1.05 \pm 0.26$ & 49 \\
\hline Threonine & $0.66 \pm 0.07$ & 40 & $0.81 \pm 0.07$ & 38 \\
\hline Tryptophan & $0.14 \pm 0.01$ & 8.4 & $0.22 \pm 0.03$ & 10 \\
\hline Tyrosine & $1.14 \pm 0.13$ & 70 & $1.17 \pm 0.08$ & 55 \\
\hline Valine & $1.06 \pm 0.11$ & 65 & $1.36 \pm 0.10$ & 63 \\
\hline
\end{tabular}

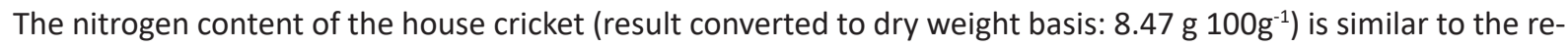
sults shown by Montowska et al. (2019), who measured nitrogen content from cricket powders (8.82 to $9.62 \%$ in dry weight) and slightly lower than in Ramos-Elorduy Blásquez et al. (2012), who measured $10.3 \%$ nitrogen

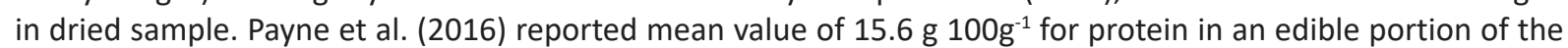
cricket. They didn't report which protein factor was used, but if it was 6.25 , the mean $\mathrm{N}$ content would be 2.50 g $100 \mathrm{~g}^{-1}$ which is slightly lower than our results. However, they also state that variation in the original data was large. High variation of protein content in Orthoptera (grasshoppers, locusts, crickets and closely related insects) is also seen in the reviews by Rumbold and Schlüter (2013) and Kouřimská and Adámková (2016). In our study, field crickets had higher nitrogen and amino acid contents (Table 3 ) than house crickets. The nitrogen content of the

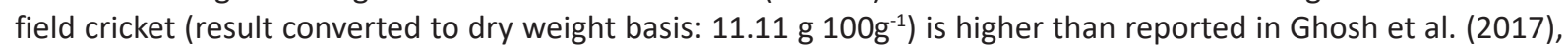
who measured $58.32 \%$ protein (that is $9.33 \%$ as nitrogen) in Gryllus bimaculatus adults. It can be concluded that our nitrogen results are in line with the previous studies.

Despite the differences in the nitrogen content and the total amount of amino acids of these two crickets, their nitrogen conversion factors were almost the same (Table 3). Considering the variations in the analysis, the factors are not remarkably different. By comparing these factors to the general conversion factor of 6.25, it is clear that non-protein-nitrogen content is more remarkable in insects than in foods in general. In this study the composition of non-protein-nitrogen part was not examined. However, according to present knowledge, it consists predominantly of chitin, inaccessible proteins, and other nitrogen containing molecules (Jonas-Levi and Martinez 2017). 
Table 3. Nitrogen contents, sums of amino acid residues, calculated $\mathrm{N}$-conversion factors, and calculated protein contents in two cricket species. (Nitrogen analysis $n=8$, amino acid analysis $n=9-18$ ). For the calculation of the standard deviation of the sum of amino acid residues, an average of the tryptophan result was used, as the tryptophan was measured from different individuals than all other amino acid residues.

\begin{tabular}{|c|c|c|}
\hline & House cricket & Field cricket \\
\hline $\mathrm{N}$ content g $100 \mathrm{~g}^{-1}$, mean $\pm \mathrm{sd}$ & $2.62 \pm 0.21$ & $3.43 \pm 0.13$ \\
\hline Sum of amino acid residues $\mathrm{g} 100 \mathrm{~g}^{-1}$, mean $\pm \mathrm{sd}$ & $13.3 \pm 1.2$ & $17.1 \pm 1.3$ \\
\hline Calculated $\mathrm{N}$-conversion factor & 5.09 & 5.00 \\
\hline Protein content g $100 \mathrm{~g}^{-1}(\mathrm{~N}$-conversion factor 6.25$)$ & 16.38 & 21.44 \\
\hline Protein content g $100 \mathrm{~g}^{-1}(\mathrm{~N}$-conversion factor 5.0$)$ & 13.10 & 17.15 \\
\hline
\end{tabular}

\section{Conclusions}

Using the universal nitrogen conversion factor of 6.25 is likely to overestimate the protein content of the crickets by $25 \%$. We have shown that for protein content, a calculation with a nitrogen conversion factor of 5.09 for house crickets (Acheta domesticus) and of 5.00 for field crickets (Gryllus bimaculatus) can be used when crickets are grown under controlled farm conditions. Based on these results, a nitrogen conversion factor of 5.0 could be applicable for both of these species. More studies are needed to show whether this nitrogen conversion factor can be used for other cricket species or when the crickets are farmed under other conditions, e.g., a different diet.

\section{References}

EC 2009. Commission Regulation (EC) No 152/2009 of 27 January 2009 laying down the methods of sampling and analysis for the official control of feed. Annex III. European Union, Brussels, Belgium, 2009.

EC 2019. Summary of applications and notifications. https://ec.europa.eu/food/safety/novel_food/authorisations/summary-applications-and-notifications_en. Accessed 4 April 2019.

Ghosh, S., Lee, S.-M., Jung, C. \& Meyer-Rochow, V.B. 2017. Nutritional composition of five commercial edible insects in South Korea. Journal of Asia-Pacific Entomology 20: 686-694. https://doi.org/10.1016/j.aspen.2017.04.003

Janssen, R.H., Vincken, J.-P., van den Broek, L.A.M., Fogliano, V. \& Lakemond, C.M.M. 2017. Nitrogen-to-Protein Conversion Factors for Three Edible Insects: Tenebrio molitor, Alphitobius diaperinus, and Hermetia illucens. Journal of Agricultural and Food Chemistry 65: 2275-2278. https://doi.org/10.1021/acs.jafc.7b00471

Jonas-Levi, A. \& Martinez, J.-J.I. 2017. Commentary - The high level of protein content reported in insects for food and feed is overestimated. Journal of Food Composition and Analysis 62: 184-188. https://doi.org/10.1016/j.jfca.2017.06.004

Jongema, Y. 2017. List of edible insects of the world (April 1, 2017). https://www.wur.nl/en/Research-Results/Chair-groups/ Plant-Sciences/Laboratory-of-Entomology/Edible-insects/Worldwide-species-list.htm. Accessed 18 November 2019.

Kouřimská, L. \& Adámková, A. 2016. Review - Nutritional and sensory quality of edible insects. NFS Journal 4: 22-26. https://doi. org/10.1016/j.nfs.2016.07.001

Köhler, R., Kariuki, L., Lambert, C. \& Biesalski, H.K. 2019. Protein, amino acid and mineral composition of some edible insects from Thailand. Journal of Asia-Pacific Entomology 22: 372-378. https://doi.org/10.1016/j.aspen.2019.02.002

Mancini, S., Moruzzo, R., Riccioli, F. \& Paci, G. 2019. Review - European consumers' readiness to adopt insects as food. A review. Food Research International 122: 661-678. https://doi.org/10.1016/j.foodres.2019.01.041

Mariotti, F., Tomé, D. \& Mirand, P. 2008. Converting Nitrogen into Protein-Beyond 6.25 and Jones' Factors. Critical Reviews Food Science and Nutrition 48: 177-184. https://doi.org/10.1016/j.foodres.2019.01.041

Mishyna, M., Chen, J. \& Benjamin O. 2020. Sensory attributes of edible insects and insect-based foods - Future outlooks for enhancing consumer appeal. Trends in Food Science \& Technology 95: 141-148. https://doi.org/10.1016/j.tifs.2019.11.016

Montowska, M., Kowalczewski, P.Ł., Rybicka, I. \& Fornal, E. 2019. Nutritional value, protein and peptide composition of edible cricket powders. Food Chemistry 289: 130-138. https://doi.org/10.1016/j.tifs.2019.11.016

Moore, J.C., DeVries, J.W., Lipp, M., Griffiths, J.C. \& Abernethy, D. R. 2010. Total protein methods and their potential utility to reduce the risk of food protein adulteration. Comprehensive Reviews in Food Science and Food Safety 9: 330-357. https://doi. org/10.1111/j.1541-4337.2010.00114.x

Mæhre, K.H., Dalheim, L., Edvinsen, G.K., Elvevoll, E.O. \& Jensen, I.-J. 2018. Protein Determination - Method Matters. Foods 7 : 1-11. https://doi.org/10.3390/foods7010005

Nowak, V., Persijn, D., Rittenschober, D. \& Charrondiere, U.R. 2016. Review of food composition data for edible insects. Food Chemistry 193: 39-46. https://doi.org/10.1016/j.foodchem.2014.10.114

Patel, S., Suleria, H.A.R. \& Rauf, A. 2019. Review - Edible insects as innovative foods: Nutritional and functional assessments. Trends in Food Science \& Technology 86: 352-359. https://doi.org/10.1016/j.tifs.2019.02.033 
Payne, C.L.R., Scarborough, P., Rayner, M. \& Nonaka, K. 2016. Commentary - A systematic review of nutrient composition data available for twelve commercially available edible insects, and comparison with reference values. Trends in Food Science \& Technology 47: 69-77. https://doi.org/10.1016/j.tifs.2015.10.012

Ramos-Elorduy Blásquez, J., Pino Moreno, J.M. \& Martínez Camacho, V.H. 2012. Could grasshoppers be a nutritive meal? Food and Nutrition Sciences 3: 164-175. https://doi.org/10.4236/fns.2012.32025

Rumbold, B.A. \& Schlüter, O.K. 2013. Review - Nutritional composition and safety aspects of edible insects. Molecular Nutrition \& Food Research 57: 802-823. https://doi.org/10.1002/mnfr.201200735

Santeramo, F.G., Carlucci, D., De Devitiis, B., Seccia, A., Stasi, A., Viscecchia, R. \& Nardone, G. 2018. Emerging trends in European food, diets and food industry. Food Research International 104: 39-47. https://doi.org/10.1016/j.foodres.2017.10.039 